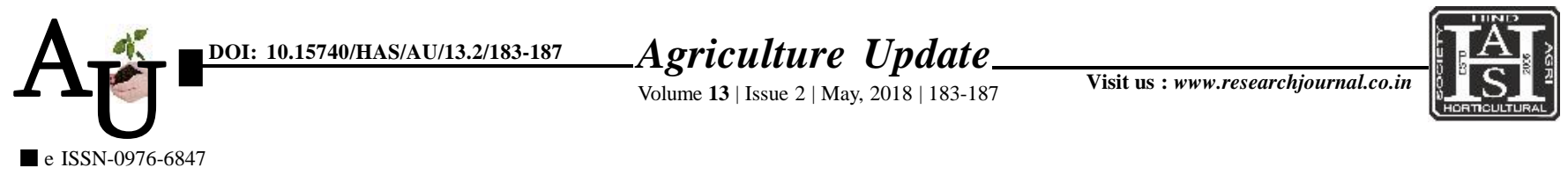

\title{
Research Article: Knowledge of Panchayati Raj Institution members regarding NRLM scheme
}

\section{Namita Shukla and Kiranjot Sidhu}

Article Chronicle : Received :

03.02.2018;

Revised :

26.03.2018;

Accepted :

11.04.2018

KEY Words:

Knowledge, Panchayati Raj institution, Role performance, NRLM more than those of other levels.
SUMMARY : Poverty is a social problem where a section of society is unable to meet even the basic needs (food, clothes, shelter, education etc) of life. Therefore, the Government of India launched the National Rural Livelihoods Mission in 2010. It aims to reach out to poor families, link them to sustainable livelihoods opportunities and help them to come out of poverty. Panchayati Raj Institutions are expected to play an important role in implementing and monitoring various developmental programmes. So it is necessary to ascertain the knowledge of PRI members about NRLM scheme and their role performance in implementation and monitoring of NRLM scheme. Descriptive research design was used and data was collected from two blocks each of four districts of Punjab state. Forty elected Zilla Parishad members, forty eight Panchayat Samiti members and ninety six Gram Panchayat members were selected from twenty four villages. Data collected through self-structured interview schedule was also analyzed using frequency, percentage, mean score and one way ANOVA. It revealed that majority of PRI members were not knowledgeable about different aspects of the NRLM scheme. More percentage of Zilla Parishad than Panchayat Samiti and Gram Panchayat were knowledgeable about their expected roles. Majority of the Zilla Parishad members who were knowledgeable about their expected roles were performing their roles. Thus, the extent of actual role performance by Zilla Parishad members under the scheme was

How to cite this article : Shukla, Namita and Sidhu, Kiranjot (2018). Knowledge of Panchayati Raj Institution members regarding NRLM scheme. Agric. Update, 13(2): 183-187; DOI : 10.15740/HAS/AU/13.2/183-187. Copyright@2018: Hind Agri-Horticultural Society.
Author for correspondence :

\section{Namita Shukla}

Department of

Extension Education and

Communication

Management, College of

Home Science, Punjab

Agricultural University, Ludhiana (Punjab) India

Email:namitapau54@

gmail.com

See end of the article for

authors' affiliations 